\title{
Land inequality and numeracy in Spain during the seventeenth and eighteenth century
}

\author{
Mari Carmen Pérez-Artés and Jörg Baten
}

KEYWORDS: land inequality, numeracy, early modern, Spain.

JEL CODES: N00, N33, N93, 018.

$W$

assess the relationship between land inequality and human capital at the end of the early modern period, focusing on individual-level evidence from Spain. Our main finding is that land inequality had already had a significant negative effect on the formation of human capital there in the late-seventeenth and eighteenth centuries. We argue that this reflects the important role of a social structure based on farming families (as opposed to latifundia and day laborers) in the development of numeracy. This is consistent with earlier studies, which argued that farming households could (1) maintain a relatively favourable nutritional standard as a precondition for cognitive skills, (2) limit child labour and (3) encourage numeracy due to its demand by farming activities. Our results are robust, as they include several control variables and potential confounding variables. 


\section{Desigualdad de la tierra y capacidad numérica en España durante los siglos XVII y XVIII}

\section{PALABRAS CLAVE: desigual acceso a la tierra, capacidad numérica, Edad Moderna, España.}

\section{CÓDIGOS JEL: N00, N33, N93, 018.}

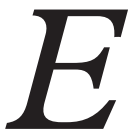
valuamos la relación entre la desigualdad de la tierra y el capital humano durante la última parte de la temprana Edad Moderna, centrándonos en la evidencia a nivel individual de España. Nuestro resultado principal es que la desigualdad de la tierra ya tuvo un efecto negativo en la formación de capital humano a finales de los siglos XVII y XVIII. Argumentamos que esto refleja el importante papel de la estructura social basada en la agricultura familiar (en oposición a la estructura social dominada por latifundios y jornaleros) en el desarrollo de la habilidad numérica, acorde con estudios anteriores que argumentaron que los hogares del campesinado parcelario podrían (1) mantener un estándar nutricional relativamente favorable: una condición previa para las habilidades cognitivas, (2) limitar el trabajo infantil y (3) fueron capaces de proporcionar habilidades numéricas básicas en las explotaciones familiares. Nuestro resultado es robusto al incluir diferentes variables de control.

Received: 2019-08-15 - Revised: 2020-03-02 - Accepted: 2020-03-09

Mari Carmen Pérez-Artés [orcid.org/0000-0001-6835-9771] is PhD at the Universität Tübingen. Address: Department of Economics, Melanchthonstrasse 30, 72074 Tübingen (Germany). E-mail: mcperezartes@gmail.com

Jörg Baten [orcid.org/0000-0001-5029-501X] is professor of Economic History at the Universität Tübingen. Address: Department of Economics, Melanchthonstrasse 30, 72074 Tübingen (Germany). E-mail: joerg.baten@uni-tuebingen.de 


\section{INTRODUCTION}

Recently, an agricultural dimension was added to the debate about the determinants of growth and obstacles to development from a long-term perspective. Galor, Moav, and Vollrath (2009) developed a model in which a stronger position for large landowners relative to industrial entrepreneurs prevents human capital formation and, consequently, economic development. In other words, the size distribution of agricultural holdings plays a central role because the political incentives of large landowners made substantial investments in human capital less likely. While entrepreneurs benefited from the accumulation of human capital by the masses and thus, had an incentive to support public education, large landowners were not willing to pay taxes for primary schooling, for example. The result of this impasse had an effect on the pace of the transition from an agricultural to an industrial economy, contributing to unequal economic growth across countries. Baten and Hippe (2018) confirmed this theory and came to the conclusion that it was mostly the agricultural south and east of Europe where large landownership restricted human capital and investment around 1900. In England, France, as well as in the most industrial parts of the Habsburg Empire, however, this effect was not visible. For the nineteenth century United Kingdom, Clark and Gray (2014) found no correlation between land inequality and literacy at a local level, as this was a country in which the industrial revolution started early. Consistently, for nineteenth century agricultural Spain, Beltrán and Martinez Galarraga (2018) used the census of 1860 and found that land inequality was negatively correlated with male education.

However, all this refers to nineteenth and twentieth century evidence, when the industrial revolution was well under way. Until now, no study has addressed this relationship for the early modern period, which is the main focus of this article. We assess the relationship between land inequality and human capital for the seventeenth and eighteenth centuries -and we can include some limited evidence on the sixteenth century as well-, focusing on individual-level evidence from Spain. Our main finding is that land inequality also had a significant negative effect on human capital formation for the early modern period. In early modern Spain, industrial development was negligible and educational investment was not very relevant for the majority of the population, hence Galor, Moav, and Vollrath's (2009) theory for the nineteenth century does not apply here, as the authors mentioned ${ }^{1}$. What was the causal mechanism instead? Building on earlier studies,

1. During the seventeenth and eighteenth centuries, the industry of Andalusia and the crown of Castile were typical of an agricultural economy with a low level of mechanization. The only two industrial Andalusian cities of the nineteenth century comparable to the Catalan or Basque provinces were Antequera and Linares (PAREJO, 2009). The Segovia textile industry or the royal textile facto- 
we argue that farming families provided a relatively favourable nutritional standard, so that their descendants could acquire human capital (Tollnek \& Baten, 2017; Baten, Crayen $\&$ Voth, 2014). Moreover, farming parents were able to provide some basic skills at home. This was very relevant for the early modern period since families were the main agents providing education during these times (Peña, 2012).

To be more specific, farmers had advantages along four causal channels: firstly, during crisis situations (the crisis of the seventeenth century, but also during short-term crises), direct access to nutrients was very important for the development of numerical skills. Malnutrition was more prevalent for agricultural sector workers who could not provide high quality food to their children, given that prices rose substantially during periods of bad harvests. The farmers, in contrast, could decide to consume more of their produce in their own households, even when high prices provided incentives to sell. This implies that farming households could access better nutrition in crisis periods, avoiding the numeracy deprivation that results from severe malnutrition, from a protein deficiency in particular (Baten, Crayen \& Voth, 2014). (2) In addition to relatively good nutritional access, many farmers' children were not burdened by child labour, whereas day labourer households depended on it, disincentivising schooling (Tollnek \& Baten, 2017). (3) Farmers were also more willing to invest in the skills of their children, as they would need them to run the farms, whereas the demand for skills by agricultural labourer parents might often have been lower (Beltrán \& Martínez Galarraga, 2018) ${ }^{2}$. We will also study below whether other social groups imitated the farmers in regions with a high farmers' share, although the evidence on this will be indirect. (4) Towards the end of the period in particular, the elites who owned land were concerned that "excessive" education of the poor would make them abandon manual labour. In the regions dominated by large-scale agriculture, the wealthy actively hindered school attendance of the lower income groups (Kagan, 1981). Only a few villages received school donations from pious or charitable señores (lords) which then benefited lower income groups. However, this was the exception rather than the rule. Kagan (1974: 25) claimed that: Consequently, Spain's peasantry, too poor to support a schoolmaster, too hard working to take time out for classes, remained overwhelmingly illiterate until the opening years of the twentieth century. As such, it seems reasonable that in areas with a lower number of landless peasants, the farmers and señores decided to invest more in education.

ries in Castile are other examples of the Spanish industry during Old Regime (GARCía SANZ, 1996; CLAYBURN LA ForCE, 1964).

2. Furthermore, although the quality of formal instruction was poor, the children of the farmers had more stable schooling over more years, even if we take the months of absenteeism due to the cycles of agricultural tasks into account (BORRÁs, 2002). 


\section{FIGURE 1}

\section{Location and sample (birth decade 1580-1760)}

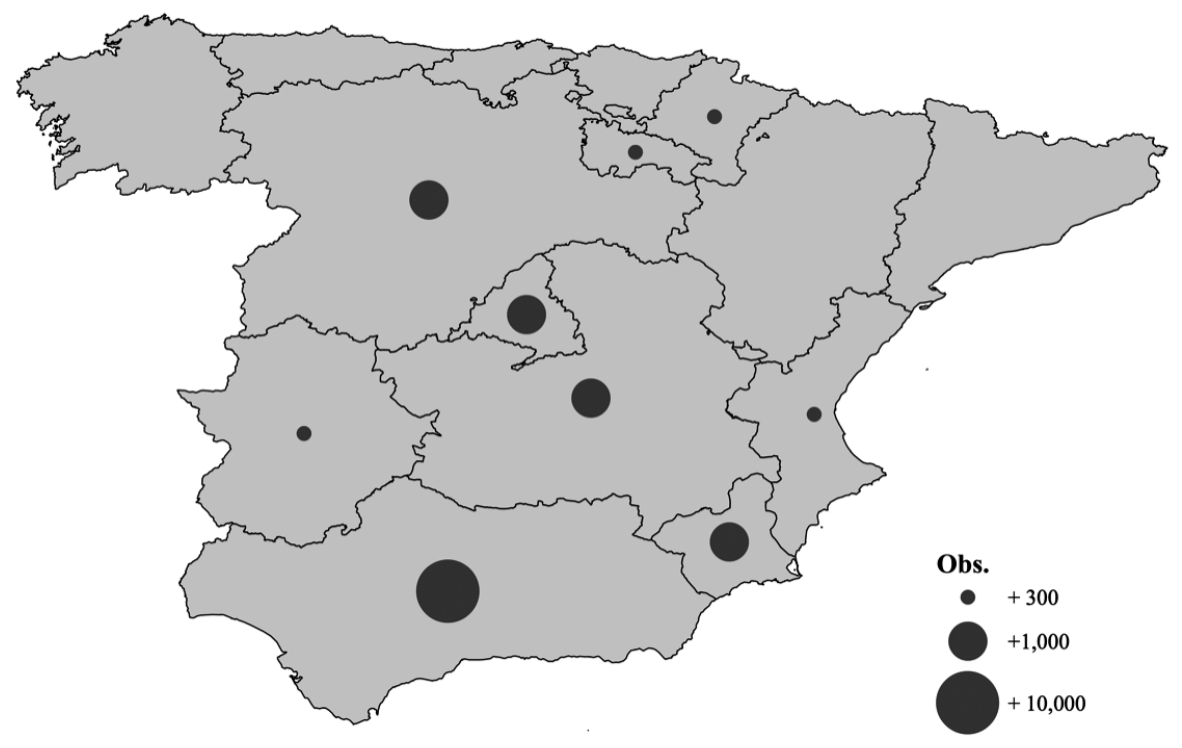

Source: see section 3 of this text.

In this article, we focus on the determinants of numeracy in early modern Spain. Due to more detailed sources -we have more evidence on Andalusia and no evidence on the Northwestern coast and Catalonia- we pay particular attention to Andalusia (Figure 1). Evidence on the sixteenth century covers two Andalusian provinces (Córdoba and Sevilla), while for the seventeenth and eighteenth centuries we have a broad mix of Spanish regions. Andalusia was an economic and urban centre during this early period; indeed, it was one of the most urbanized regions across Europe ${ }^{3}$. This region is the southernmost point of mainland Europe and, with more than 87,000 square kilometers, its area is larger than several European countries (Parejo, 2009: 11) ${ }^{4}$. Another important fact is that Andalusia benefited from the accumulation of colonial traffic with America; it was the starting point of the trade with the New World. Sevilla particularly enjoyed its monopoly in trade with America from the sixteenth century, until it was overtaken by Cádiz in 1717 (Marcos, 2000).

3. The current term Andalusia comes from the territorial reform of 1833, when this domain included the Kingdom of Granada. Previously, it referred to the Kingdoms of Córdoba, Sevilla and Jaén, incorporated into the Crown of Castile in the thirteenth century (PAREJO, 2009).

4. Andalusia is larger than Ireland, Luxembourg, Denmark and Belgium. 
A new dataset from padrones (local nominative population censuses) and Cadastre of Ensenada is analysed here ${ }^{5}$. Table A1 offers a description of the sources. Although more than half of our sample is from Andalusia, we were able to include other regions in Spain to obtain more representative results. We weight our analysis, below, to give the central and northern regions their appropriate influence on our results. The sample covers the period from 1580 to the middle of the eighteenth century. Our sample is composed of 26,851 individual observations mentioning age, of which 17,145 also contain occupational data. This evidence allows us to provide a long-term perspective of land inequality and numeracy.

As far as we are aware, until now, no individual-level analysis on this topic exists for early-modern Europe. Only in Spain, and in Andalusia in particular, were local censuses containing both ages and occupations taken from as far back as the sixteenth century. We use the inequality proxy suggested by Clark and Gray (2014) as our main explanatory variable. This proxy is based on the idea that in regions where large estates were prevalent, the agricultural workforce mainly consisted of agricultural labourers who did not own farms and were not called farmers. In contrast, in regions of small and medium sized farms, farmers represented a high share of the agricultural workforce ${ }^{6}$.

We use age-heaping-based estimates of numeracy for the dependent variable. The underlying methods were developed in the last decade, especially for societies and periods where sources of other education indicators were incomplete. Numeracy, or the ability to deal with numbers, allows us to obtain a more comprehensive sample from early modern Spain. Age statements can be found in a greater number of sources than alternative measures of human capital (A'Hearn, Baten \& Crayen, 2009). This proxy has also been used by Álvarez and Ramos (2018) to assess the relationship between human capital and male labour earnings in Spain for the provinces of Palencia, Guadalajara and Madrid. They found that numeracy had an influence on earnings, supporting the relevance of numeracy among economies in early modern Spain. The relationship between numeracy and economic growth is even stronger than that for school enrolment or literacy, as the recent economic growth literature has shown: Hanushek and Woessmann (2012), for example, argued that math and science skills were crucial for economic success in the twentieth century. They concluded that numerical skills matter the most for economic growth

5. The Catastro of Ensenada (1750-56) is the name given to the investigation carried out in the territories of the Crown of Castile on the property and income of the householders, as well as on their family and servants (CAMARERO, 2002).

6. This proxy has also been used in the nineteenth century study of BELTRÁN and MARTínez GALARRAGA (2018). 
by considering cross-country evidence as well as the success of migrants from various countries to the US, for example.

The remainder of the paper is structured as follows: section 2 introduces the historical context of land inequality and human capital in modern Spain; section 3 follows with the explanation of the methodology and the data used in this study; in section 4, our empirical results and descriptive analysis are presented; section 5 presents the conclusions.

\section{LAND INEQUALITY AND HUMAN CAPITAL IN MODERN SPAIN}

\subsection{The origin of land inequality}

The agrarian reform law of September 1932 blamed the latifundium for the backwardness and the pitiful conditions of the workers in the countryside (González de Molina, 2014: 28) ${ }^{7}$. However, Carmona and Simpson (2003: 19) argued that these institutions were not the cause of the low levels of production and productivity, rather that latifundia "reflected" the low level of development in agriculture. Our study combines these views by studying whether regions dominated by farming households displayed higher levels of numeracy.

We first provide some detailed background on Andalusia, the region for which we have ample evidence. We later discuss the -often middle-sized-farm characteristics of central and northern Spain. The structure of landownership in Andalusia was characterised by, on the one hand, a large share of large landholdings in the kingdoms that had been incorporated into Castile in the thirteenth century and, on the other hand, a majority of small properties in the Kingdom of Granada (Parejo, 2009). In the Guadalquivir valley, large landownerships were predominant. As early as the fourteenth century, the nobility was interested in these lands and accumulated them in a regimen of large properties, being fully consolidated by the middle of the eighteenth century. Both the high nobility and the lower regional nobility owned very large estates in municipalities of the Guadalquivir riverside (Mata, 1984). On the other hand, in Granada and Almería, the formation of latifundia began later and was restrained by the mountainous terrain of the area. This was

7. Latifundia refer to the large private farms in the south of Extremadura, Castile and the Guadalquivir Valley. Apart from the predominance of large rustic patrimonies and latifundia, the irrigated agriculture of the interior of Andalusia and Murcia and the production of wine regions of the south required a large workforce and therefore, of a large number of day labourers (GONZÁLEZ DE Molina, 2014). 
favourable for small and medium farmers and for the repopulation after the Morisco uprising of $1568-70^{8}$. After this event, the state distributed additional plots to Christian settlers and also prevented the accumulation of latifundia ${ }^{9}$.

Warlords, nobles and clergy were the main beneficiaries of the Castilian conquest of $\mathrm{Al}$ Andalus. From the thirteenth century onwards, the concentration of landownership increased due to the purchase and sale of land by privileged groups, such as titular nobility and urban merchant classes. This development also explains the elements of the day labourer (jornaleros) in Andalusia. Although, in the east, large properties were less represented in rural areas, day labourers made up the majority of the population on the Mediterranean coast (Arenas, 2016). During the modern era, the power of rural elites increased. These elites originated in the lordships that were granted during the reign of the Catholic Monarchs, especially related to the conquest of Granada. These oligarchs were enriched through the accumulation of land, leases and cereal specialisation. Whether through economic, family or political ties, wealthy farmers had access to the privileges of the nobility. During the reigns of Charles V and Philip II, the local lords and oligarchies usurped communal lands in southern Spain that had been fundamental for the subsistence of the peasant economies. Day labourers suffered from long working days and low wages (Peña, 2012) and, by the end of the eighteenth century, the nobility, the church and municipalities owned most of the land (Carmona \& Simpson, 2003) ${ }^{10}$. Later on, during the nineteenth century, landless peasants still had to endure the poor conditions of income and labour, while rich landowners found enough workers for their estates (González de Molina, 2014). However, in the nineteenth century, land accumulation decreased among the privileged classes of the old regime, and during the next century, the predominant landowner class of the southern latifundia began to lose political prominence in state government as well as at the regional and local levels (Mata \& Naranjo, 1997).

8. This uprising had its precedent in January of 1567, when a royal law obliged all Moriscos (Muslims forcibly converted to Christianity) to become "real" Christians within a year. This episode, also known as the war of the Alpujarras, is the last episode of the Islamic and Christian conflict that lasted almost eight centuries. This rebellion ended with a massive deportation of all previously Muslim families of the Kingdom of Granada. In 1609, the expulsion of the last Moriscos from Spain took place (ANDÚJAR, 2004).

9. Calculating the share of agricultural area relative to the total area, the lowest proportion was only $35 \%$ in the Kingdom of Jaén while Sevilla and Córdoba had 59\% and 57\% respectively. $61.8 \%$ of the Kingdom of Granada was agricultural due to the better utilisation of land caused by a more rational division of land than in the Guadalquivir Valley (see also ArTOLA, Bernal \& ConTreras, 1978).

10. For central Spain, SANTiago-Caballero (2011) demonstrated that the income inequality among grain producers decreased in Guadalajara at the end of the eighteenth century. It was due to the possibility that small peasants had to increase the size of their lands as a result of the redistribution of common lands privatized by the central government. 
As stated above, two and a half centuries separated the conquest of Lower Andalusia and the Kingdom of Granada, which led to some institutional differences between both territories. Furthermore, after the Conquista, the repopulation of the Bético valley mainly consisted of people coming from northern Spain, whereas the one of the Granada region was administered by the western Andalusians ${ }^{11}$. Another peculiarity was the presence of a substantial Muslim community in eastern Andalusia. Even after the expulsion of the Muslims, the socioeconomic and institutional reality in the Kingdom of Granada was different from the prevailing situation in Jaén, Córdoba and Sevilla. In the eighteenth century, the dissimilarities within Andalusia were also visible in economic indicators such as the ratio between the number of day-labourers and farm owners. The share of farmers (labradores and hortelanos, taking only males) relative to the total number of male occupations (males, age 25+) in 1785-87 according to the census of Floridablanca is, in this sense, quite heterogeneous between Andalusian regions: in the provinces of Almería and Granada, this farmers' share was as high as $42 \%$ and $31 \%$ respectively; it was $24 \%$ in Jaén, and $20 \%$ in Málaga, 14\% in Sevilla and 18\% in Córdoba and a negligible $6 \%$ in Cádiz ${ }^{12}$. In central and northern Spain, the farmers' share was much higher: Navarra and Guadalajara had the highest shares (84\% and 64\%). However, the farmers' share is not just a correlate of the north-south differences. For example, La Rioja had a relatively low farmers' share $(29 \%)$, a rate that was below that of provinces such as Almería, Cáceres (42\%) and Badajoz (40\%). Here and in the following we distinguish between "provinces" and "regions", the latter comprising several provinces (the regions are visible in Figure 1, provinces are compatible to today's provinces).

\subsection{Human capital in Spain since the sixteenth century}

A widely used indicator for studying human capital in pre-census periods has been literacy. Several studies used the ability to sign as a proxy for literacy (Delgado, 1993; Viñao, 1999). The presence or absence of signatures on documents was considered the only direct evidence for measuring education levels. Only in 1797, with the census of Godoy, data about the schooling process became available. Finally, in 1860, a Spanish census included information about the ability of inhabitants to read and write for the first time. Núñez

11. The term Bético refers to the provinces of Córdoba, Sevilla, Huelva, Jaén, and Cádiz.

12. Ponsot (1986: 28) studied the distribution of the property for 17 municipalities in western Andalusia by the middle of the eighteenth century. Only in two cases he found that small and mediumsized owners had some relevance (Espartinas and Montilla located in Sevilla and Córdoba) while the major owners were the majority (for example, Carmona and Medina Sidonia in Sevilla and Cádiz). 
(1992) studied and analysed the relationship between human capital and economic growth in contemporary Spain, exploiting this source.

The ability to sign has allowed researchers to estimate levels of literacy for different regions of Spain. However, one of the problems with this method is the representativeness of the available samples; the types of sources (fiscal sources, testimonies, marriage records, etc.) are usually not uniform for all regions or even within the same location for different years. In addition, the same sources often have different levels of representativeness; for example, sometimes the samples represent only the wealthier and presumably more educated social strata which makes it difficult to reach conclusions (Viñao, 1999). These studies reveal that the capacity to sign increased during the sixteenth century, but decreased again in the seventeenth century (ibid., 1999). Rodríguez and Bennassar (1978) studied the interior Andalusian regions of Andújar, Iznatoraf, Úbeda and Córdoba using the testimonies of the accused during the inquisition.Vincent (1987) used fiscal sources and assessed the literacy of the Moriscos in Granada in 1570. Literacy in Cádiz has also been explored by M. J. de la Pascua (1989) using wills during the late seventeenth century.

Throughout our period, the family was the main agent providing education. There was substantial numeracy in Spanish farm households before the widespread introduction of schooling, hence the acquisition of numerical skills could only have happened in the family and the household (Tollnek \& Baten, 2017; Borrás, 2003; Álvarez \& Ramos, 2018). Only very few families could afford a teacher during the early modern period. For the children of the poorest neighbourhoods, the local communities and parishes sometimes paid an annual amount to a teacher, but schools were few. Moreover, the control over the training of teachers would not begin in Andalusia until the beginning of the eighteenth century (Peña, 2012).

During the eighteenth and nineteenth centuries, when local communities in some parts of Europe paid for teachers and schools, the large Andalusian landowners were not interested in paying taxes to promote education for their day labourers. As Arenas (2016: 375) has claimed: illiteracy and the absence of training contribute to immobilizing the labour force in the territory, thus promoting the excess of labour and, consequently, low wages. Apart from low wages, day labourers had to face times of unemployment due to bad weather or times when there was no work in agriculture (Bernal, 1987; Carmona \& Simpson, 2003). This is consistent with the findings of Álvarez and Ramos (2018) for Guadalajara, Madrid and Palencia where human capital influenced male labour earnings during the eighteenth century. In contrast to Denmark, which developed a human capital-intensive 
form of agriculture, the proximity of owners to agricultural production was not given, in addition to a number of other differences ${ }^{13}$.

Andalusia did not reach levels above $30 \%$ of literacy until the twentieth century. The western provinces, rural areas and the female population had the lowest literacy rates (Arenas, 2016: 351; Sarasúa, 2002). At the national level, in 1900, Andalusia held an average position in terms of literacy; but by 1950, it had dropped to the lowest level in all of Spain (Arenas, 2016: 352).

\section{METHODOLOGY AND DATA}

The regions considered in this research are illustrated in Figure 1. Table 1 specifies the number of observations by province and period. Table A1 in the appendix contains a description of the sources ${ }^{14}$.

To measure land equality, we use the ratio between the number of farmers and the overall agricultural population, an indicator suggested by Clark and Gray (2014). Our definition of farmers depends on the contemporaneous naming of occupations. "Farmers" (labradores) were not only those who owned land, but also those who rented land and ran a farm of a substantial area. Hence, a day labourer (jornalero) who was usually not possessing or controlling land, would not be identified as farmer by contemporary census takers (Tollnek \& Baten, 2017). Although quantitatively almost irrelevant, we also include hortelano in the same category as farmers, since they usually also had some control over plots of land that were intensively farmed and they could provide better nutrition to their children in crisis situations ${ }^{15}$. Although hortelanos were obviously not farmers, we included them for simplicity in the variable farmers'share (justified by their small number). In order to assess the plausibility of the farmers' shares based on our sample, we can calculate a similar farmers' share for the Floridablanca census (even if the Floridablanca census was recorded somewhat later, in 1785-87). The correlation is very strong (Figure 2, aggregated on province level). A large share of both our-sample-based farmers' shares and the Floridablanca-based farmers' shares are in the 20 to $40 \%$ range. Our sample is slightly

13. In the case of Andalusia, large absentee landowners owned extensive properties in the South (CARMONA \& SimPSON, 2007). Although absenteeism could be an obstacle to promoting human capital, it does not seem to have affected agricultural production (SIMPSON \& CARMONA, 2017).

14. Within these sources, we analysed a convenience sample and we took care not to select only special groups.

15. The difference between labrador and hortelano lies in the type of land they own. For the former it was rain-fed for the latter it was irrigated (BERMÚdEZ MÉNDEZ \& MARTín, 2007). 
more urban (hence a lower farmers' share for Sevilla, for example) and more Andalusian. This difference is mostly compensated for by our weighting procedure.

\section{FIGURE 2}

\section{Comparison of the farmers' share in the Floridablanca census and in our sample}

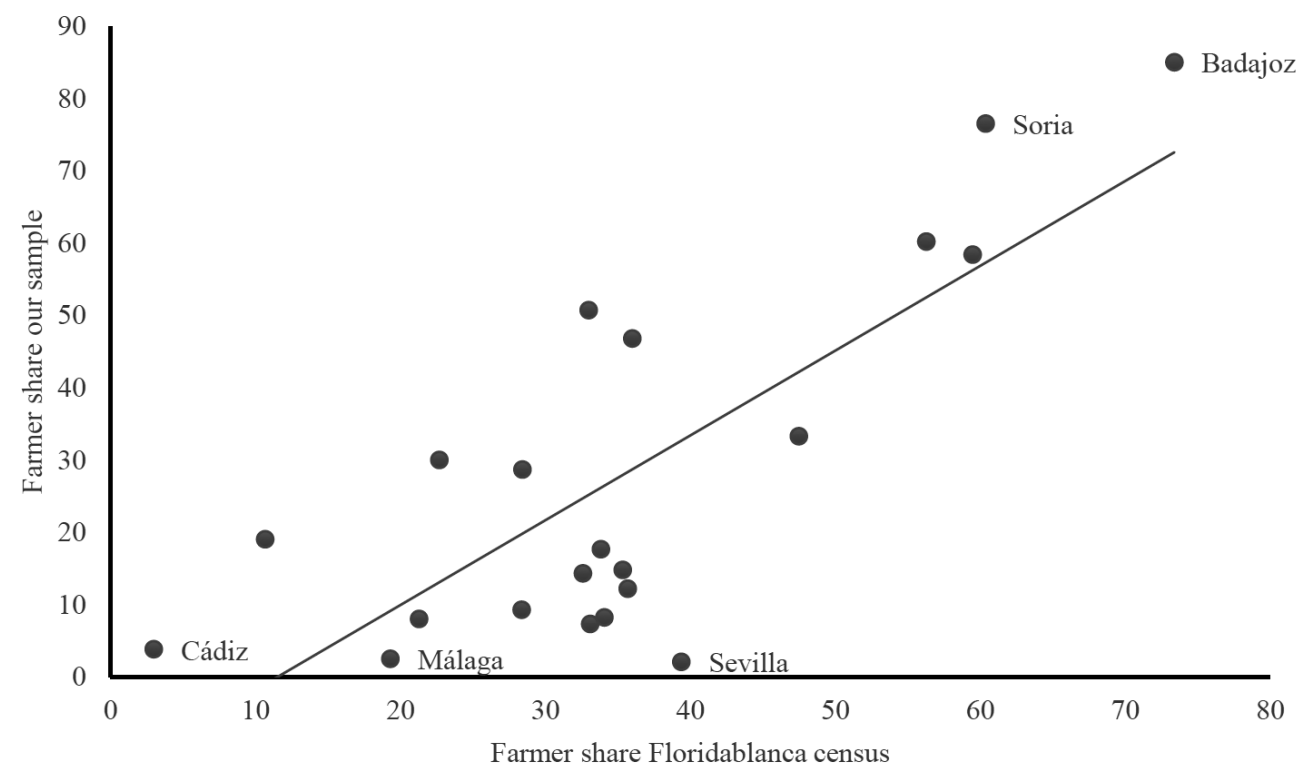

Note: we aggregate the farmers' share here for only the local communities for which we have numeracy data. For example, Murcia is only represented by Lorca, Valencia only by Sueca. Consequently, this comparison does not aim at representativeness for the provinces.

Source: see section 3 of this text.

In order to assess numeracy, we employ the "age heaping" methodology using the ABCC index ${ }^{16}$. This method considers the share of individuals who are able to state their precise age in years, in contrast to those who report an age rounded to a multiple of five. For instance, an individual could state "I am 45 " when he or she is 44 in reality, but did not know it exactly. Numeracy and literacy are robustly correlated, though basic mathematical skills diffused earlier than literacy. In addition, the potential biases caused by counting cultures and the institutional settings of censuses have been thoroughly discussed throughout the numeracy literature, but the results did not invalidate the age heaping method (Tollnek \& Baten, 2017). Accordingly, we can argue that, just as signature rates in official documents, despite their limitations, can serve as proxy for basic literacy (Reis,

16. The term $A B C C$ results from the initials of the authors' last names plus that of Gregory Clark, who commented on their paper. 
2005; Rodríguez \& Bennassar, 1978), age heaping can serve as a proxy for basic numeracy.

The ABCC index is a simple linear transformation of the Whipple index (1), derived by A'Hearn, Baten, and Crayen (2009). The ABCC index (2) allows for an easier interpretation and yields an estimate of the share of individuals who state their age precisely:

$$
\begin{aligned}
& \text { (1) } W h=\left(\frac{(\text { Age } 25+\text { Age } 30+\text { Age } 35+\cdots+\text { Age } 60)}{\frac{1}{5} \times(\text { Age } 23+\text { Age } 24+\text { Age } 25+\cdots+\text { Age } 62)}\right) \times 100 \\
& \text { (2) } A B C C=\left(1-\frac{(W h-100)}{400}\right) \times 100 \text { if } W h \geq 100 ; \text { else } A B C C=100
\end{aligned}
$$

This index ranges from 0 to 100, where 100 indicates no heaping patterns on multiples of five, meaning that the entire society has skills in basic numeracy. The age groups we use are in increments of ten years; 23 to 32,33 to 42, etc. We omitted the age range 63 to 72 , as this group offers relatively few observations, especially for the seventeenth and eighteenth centuries when mortality was relatively high (Schofield \& Reher, 1994). Crayen and Baten (2010) analysed age effects carefully and found that they do not have a strong influence once the birth cohort effect is controlled for: older individuals may round more strongly, but mostly because they were born earlier. The only exception is the youngest group, age 23-32, which needs an adjustment of $25 \%$ that we calculated in our sample (Crayen \& Baten, 2010) ${ }^{17}$.

While the ABCC index refers to averages of groups (by region and birth decade, for example), it is also possible to analyse the likelihood of individuals to report a rounded age. This can be done by assigning the binary variable numerate which is coded as 1 for those who report an unrounded age and 0 otherwise (Juif \& Baten, 2013; Tollnek \& Baten, 2017). The binary variable can be analysed with Logit or Probit regression models or by using a linear probability model (LPM) with heteroskedasticity-robust standard errors.

17. Moreover, a potential bias could result from counter-checking by the officials who collected the local censuses. We looked at each source by itself to assess whether numeracy was close to $100 \%$ in local communities and times in which this could not be expected. This phenomenon of counterchecking occurred in some Russian and Korean sources, for example, as described by BATEN, SzOŁTYSEK and CAMPESTRINI (2017) as well as BATEN and SOHN (2017). They therefore decided to discard a part of their sources. In Spain, government officials were not counter-checking sources to the same extent, as we do not observe this phenomenon of numeracy being very close to $100 \%$. 
For the result to be interpreted in ABCC-values under the LPM, it needs to be multiplied by 125 (by 100 to move from a fraction between 0 and 1 to a percentage, and by an additional 25 to account for the fact that $20 \%$ of the population actually do have ages ending in 0 or 5 ).

How representative is the sample? Fortunately, the availability of evidence in Spain resulted in a quite widespread geographic distribution (Figure 1). Most regions can be covered in the seventeenth and eighteenth centuries, except the northwestern coast and Catalonia. We have more observations on Andalusia, but we can adjust this overrepresentation by assigning smaller weights to Andalusian observations and larger weights to the other provinces (see the notes in Table 3 for details). Socially, our local censuses are quite representative, because they include all social strata, as can be seen from the occupational information. We also took care that we did not only record a special effect in the Cadastre that might have reflected a special sub-population (such as the nuns in a monastery or the merchant quarter of a city, for example). We have rather drawn samples that cover various parts of cities and villages, if the archival situation allowed us to do so. As a definition, we will call cities and villages local communities in the following. In general, we distinguish between local communities, provinces and regions (as in Figure 1).

Finally, is the population of each local community sufficiently covered by at least some observations? We calculated the approximate share of our sample, relative to the total population in the earliest reliable census, the Floridablanca census $(1785-87)^{18}$. As a result, in only 10 local communities, our sample represented less than $10 \%$ of the total population older than 25 years of age, while for 48 local communities we could obtain more than one tenth of the overall population (see Table A2 in the appendix) ${ }^{19}$. As there were differences in the archival survival rates in various local communities, we needed to weigh the samples in order to obtain regional representativeness anyways.

18. Using this census, we calculated the inhabitants who were more than 25 years old (given the way in which the Floridablanca census aggregates the information, it is not possible to take it from 23 years of age) by local community. We divide the number of persons in our sample by the census total, even if our sample refers to an earlier period. Due to the lack of reliable census sources for occupations in the sixteenth, seventeenth and early eighteenth century, it is not possible to obtain reliable census totals per local community for earlier periods.

19. The ten cases of less than $10 \%$ refer mostly to Andalusia, for which we have overall a very high number of observations anyways. In other words, if we would have a $10 \%$ share for these Andalusian local communities, our regional representativeness would actually be smaller. The same is the case for the urban share -our sample has slightly more urban cases than the general Spanish population, hence we would have a less representative sample, if Écija, Córdoba etc. would be presented by a $10 \%$ sample. 
Finally, we analysed whether the observations for which we have occupations and those for which we do not have occupations are comparable. The numeracy index of those with occupations was 64.3 and the one without occupations was 66 . Hence the numeracy index difference is only 1.7 points, which is a very small difference that can easily be caused by composition effects.

\section{DESCRIPTIVE ANALYSIS AND REGRESSION RESULTS}

Table 2 shows the descriptive statistics. The mean of the variable numerate in our sample is 0.57 , which indicates that slightly less than a half of our sample reported an age ending in 0 or 5 . The mean farmers' share, which is our main explanatory variable of interest in this study, is 0.33 , with a standard deviation of 0.27 , defined as fraction of occupations between 0 and 1 .

In order to assess the influence of the farmers' share on numeracy, we performed logit and linear probability model (LPM) regressions. The LPM is described in the following equation, which applies similarly to the logit model.

Numerate $_{\text {itr }}=\alpha+\beta_{1}$ Farmershare $_{\text {tr }}+\beta_{2}$ Farmer $_{i}+\beta_{3}$ age23-32 $_{i}+\beta_{4}$ age43-52 $i$ $\beta_{5}$ age 53-62 $2_{\mathrm{i}}+\beta_{6}$ City $_{\mathrm{r}}+\beta_{7}$ Female $_{\mathrm{i}}+\mu_{\mathrm{r}}+\gamma_{\mathrm{t}}+\varepsilon_{\text {itr }}$

${ }_{\mathrm{i}}$ indicates each respective individual, $\mathrm{t}$ indicates the decade of birth, and $\mathrm{r}_{\mathrm{r}}$ denotes the region in which the individual was born at the local community level. The variable to be explained is numerate, coded as 0 when age is stated as a multiple of five, and 1 otherwise. Farmershare is the proportion of farmers in the agricultural sector of our sample and Farmer is a dummy for farmers. Age23-32 corresponds to the group of individuals aged between 23 and 32, following the same idea for Age43-52 and Age53-62. City is a dummy for cities with more than 20,000 inhabitants according to the Floridablanca census carried out in 1787 and Female is a dummy for females. The model includes region fixed effects $\left(\mu_{\mathrm{r}}\right)$ that reflect the historical regions in Spain from Figure 1. We also control for time fixed effects $\left(\gamma_{\mathrm{t}}\right)$, using half-century periods from 1580 to 1760 . Finally, the equation allows for a constant term $(\alpha)$ and an error term ( $\varepsilon_{\text {itr }}$. The model is also weighted by the proportion of inhabitants by historical regions in the Aranda census $(1768)^{20}$.

To measure the effect of farmers' shares on numeracy, based on the occupational information for 17,145 cases, we calculated the farmers' share of each local community and

20. See note Table 3 . 
period. Our inequality data provide 117 observations combining local communities and birth centuries. We then assigned this farmers' share in a given local community and century to all 26,851 individuals: we include all cases where age is reported, even if occupational information is not contained for each individual, but for a sufficient number of occupations in a specific local community and birth century.

Table 3 shows the results of the effect of farmers' shares on numeracy. We cluster the observations at the local community and birth decade level. Weights establish representativeness for the regions included in columns 2 and 3, but there is not a substantial difference to the unweighted regression in column 1 . Columns 1 and 2 include both males and females. In the last column, we only analyse the males of our sample. We control for the characteristic of being a farmer and different groups of age ${ }^{21}$. Interestingly, if we include the inequality proxy farmers'share the farmer coefficient by itself does not show a significant difference, relative to persons who are not farmers ${ }^{22}$. Consequently, we conclude that the social structure in regions with high farmers' shares also affected numeracy beyond the farmer group itself. The only logical explanation for this are external effects: people with other occupations (for example, craftsmen and skill-intensive services) who lived in regions dominated by farmers behaved more similarly to -and perhaps imitated-farmers, compared to craftsmen and others in regions not dominated by farmers, but by agricultural day labourers and latifundia: the ones in the farmer-dominated regions also invested more time in their offspring, sent their child less often to work, and provided slightly higher quality of nutrition than in the latifundia regions. We do not have direct qualitative evidence on this, but presenting this indirect quantitative evidence on these external effects is already interesting.

As a caveat, we note that the number of cases in our individual-level regression should not be taken as proof of high reliability, as the explanatory variable farmers'share varies by local community and century. Nevertheless, in all specifications, our equality measure farmers' share had a large positive impact on numeracy. The variable city never appears significantly correlated. In this analysis, females do not have a significant disad-

21. Following REHER (1994), we categorise the region as rural for local communities with less than 5,000 inhabitants, urban with more than 5,000 and city with more than 20,000 inhabitants. Unfortunately, we cannot control for local community fixed effects, as this would move the focus to the modest variation over time, which would seem less reliable -considering potential measurement errorcompared to the substantial cross-sectional variation in our sample.

22. Some of the coefficients for higher ages are statistically significant and negative, which might be either caused by the fact that people tend to forget their ages when they reach their 50s and 60s years of age, or by the fact that they were born in earlier birth decades. The research by CRAYEN and BATEN (2010: Appendix) suggests the latter. 
vantage once we control for farmers' share. It should be taken into account that mothers had a very important role in farming households (Tollnek \& Baten, 2017). Table 4 performs the same analysis in a logit model. The results are nearly the same as those obtained in the LPM. R-Squares are generally low, suggesting that at the individual level a substantial random variation accounts for large part of the overall variation. However, the pvalue of significance suggests that the farmers' share has a substantial influence.

FIGURE 3

\section{Relation of residual farmers' share and residual numeracy, on a provincial aggregate level}

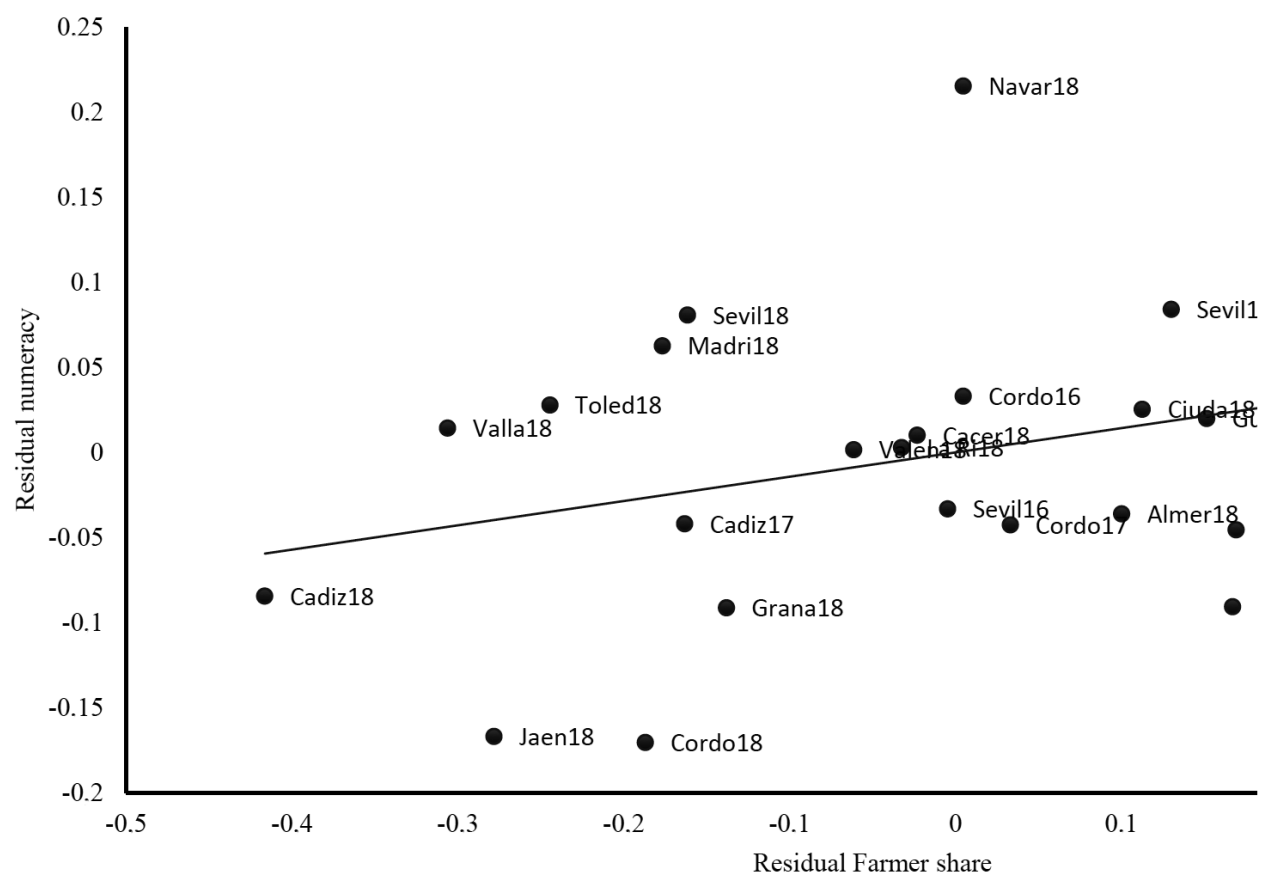

Note: in the regression analysis, we used 117 local community-birth century units. Here we aggregated by province and birth century, in order to make the figure more easily understandable.

Source: see section 3 of this text.

To test whether the results are potentially driven by a small number of outliers, we construct a residual plot by regressing numeracy on the most important explanatory variables (city, female, and century fixed effects Figure 3). In a second step, we regress the main explanatory variable of interest, the farmers' share, on all of these variables except numeracy. In both steps we saved the residuals, of numeracy and farmers' share, respectively. These can be interpreted as the residual value of both variables, after removing the influence of the other explanatory variables. In order to make it easier to interpret, we ag- 
gregate all locations at the provincial level and century. For example, our evidence on Cuenca, Soria and Ávila had a high land equality (indicated by the high residual farmers' share) in the eighteenth century, and at the same time a high residual numeracy. In contrast, eighteenth century Cádiz, Jaén and Córdoba had both low residual land equality and numeracy ${ }^{23}$. Outlying observations to the upper left were Sevilla, Madrid and Navarra: residual numeracy was higher than expected based on land inequality. For Sevilla and Madrid, the urban effect might be particularly important and not be fully captured by the large-city-dummy variable (which was also assigned to smaller urban centres) ${ }^{24}$. Murcia had a relatively low level of numeracy in spite of its comparatively high land equality (but it should be noted that Murcia is only represented by Lorca). This might be caused by the difficulties in maintaining Murcia's irrigation agriculture in the eighteenth century due to the lack of water and due to privatization during the seventeenth and eighteenth centuries. Concentration and privatisation affected not only day labourers, but also farmers in Murcia. Only the landlords from the capital, who received regular payments from their tenants, benefited from it (Pérez Picazo \& Lemeunier, 1985). However, in sum, we observe that residual numeracy strongly corresponds with the residual farmers' share.

We also considered endogeneity and a potentially confounding role of skill-selective migration (Appendix B). Both these potentially confounding factors appear to have only a very modest influence on the results.

How large are the numeracy differences between farmers and agricultural labourers individually? While we already included a farmer variable in the previous regression comparing farmers with non-farmers, here we are interested in the differences between farmers and day-labourers, as well as the differences between other occupational groups and day-labourers. Hence, in the first column of Table 5 we test the difference between being a day-labourer and having a non-agricultural occupation or being a farmer. In the first column we include region fixed effects. In the second, we use fixed effects for each local community. In both models, time fixed effects are also considered. In both cases, the coefficients of numeracy for the farmers are significantly positive. In other words, we observe that the difference in numeracy between farmers and day labourers was 7.1 percentage points in the first specification and 4.8 in the second, which controls for local community fixed effects. This result is smaller, but with the same sign as in Catalonia in the eighteenth century, where the farmers had a 14 percentage point advantage (Gómez-i-

23. There is a high intertemporal persistence, as BELTRÁn et al. (2018) found for the nineteenth and twentieth centuries that the lowest numeracy indices were also in the Andalusian provinces.

24. For Navarra, we cannot exclude the possibility that the sample is too small to yield a reliable estimate. 
Aznar, 2019). In sum, the agricultural day-labourers had a much lower numeracy level than the non-agricultural occupations (i. e. services and crafts).

\section{FIGURE 4}

Numeracy of farmers, agricultural labourers and other occupations

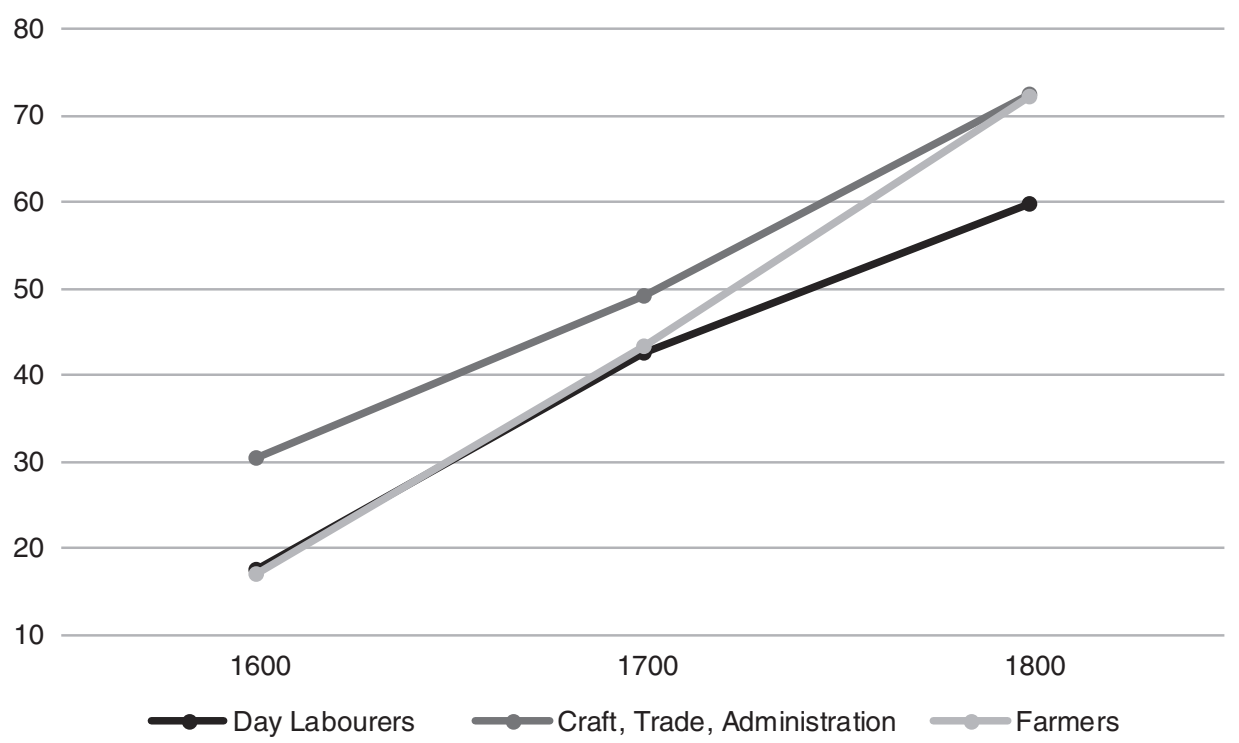

Note: 1600 refers to Andalusia only (Córdoba and Écija), 1700 and 1800 to all of Spain.

Source: see section 3 of this text.

How did these numerical differences develop over time? Figure 4 portrays the numeracy trends by occupation groups for the sixteenth to the eighteenth century. The sixteenth century evidence cannot be directly compared in level terms, because we have only three Andalusian regions for the sixteenth century. But the relative numeracy ranking of occupations might still be interesting: farmers, day labourers and other occupations had much lower numeracy in sixteenth century compared to the seventeenth century across Spain. Moreover, for the seventeenth and eighteenth centuries, we have evidence on all regions. We observe that the farmers started at the same level as the day labourers in Andalusia in the sixteenth century. For the regionally broader data of the seventeenth century, numeracy was much higher for all occupation groups. Farmers and day labourers both still had quite low numeracy. By the eighteenth century, farmers almost reached the level of tradesmen, craftsmen and workers in administration. The gap in numeracy between farmers and the rest of the agricultural sector confirms earlier research about inequality in Spain by Álvarez Nogal and Prados de la Escosura (2013), who found an increase in Spanish inequality (and land rent to wage ratios) from the early sixteenth century, after the 
Spanish medieval economy, with its strong urban and pastoral elements, disappeared (see Santiago-Caballero, 2011 on Guadalajara).

\section{FIGURE 5}

Share of farmers in Córdoba and Écija (the two local communities with continuously reported occupations), relative to other day labourers

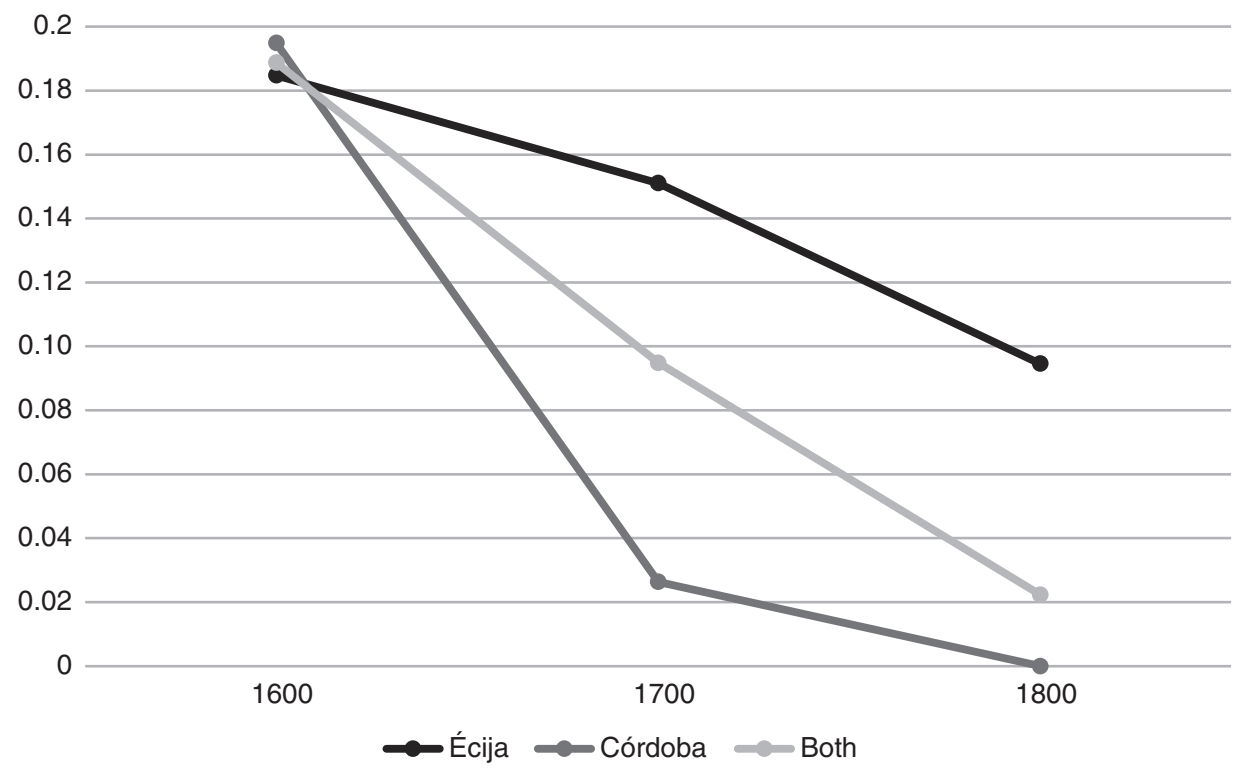

Source: see section 3 of this text.

The final question is whether the farmers' share remained stable over time, increased or declined. We can only trace this trend for all three centuries for Córdoba and Écija, located in Andalusia, where occupation was reported systematically for all the three periods. We observe that the farmers' share fell from around $18 \%$ to $2 \%$ between the sixteenth and eighteenth century (Figure 5). Clark and Gray (2014) argued, that this indicator proxies equality, hence we observe a strong increase in inequality, but with some caveats in this case: in two cities, the outskirts had a substantial share of farmers in the early period, but this phenomenon vanished over time as farmers disappeared in the larger towns, according to our evidence. Whether a similar decline from a higher starting point occurred, as in Córdoba and Écija, cannot be assessed for lack of evidence. To the extent that Córdoba and Écija are representative, this might reflect a tendency of declining farmers' shares in Andalusia overall. Bernal (1987:3) has shown that the number of day labourers for a sample of 20 local communities in Sevilla represented 54\% of the workforce in 1620, increasing to $70 \%$ in 1754 . By the end of the eighteenth century, this group would be $78 \%$, on average, for the four Andalusian kingdoms, reaching their maximum in Sevilla and Cór- 
doba. It would be one element implying slower numeracy progress in this region, relative to other European regions ${ }^{25}$.

\section{CONCLUSIONS}

We conclude that the land equality indicator farmers'share always had a significant positive effect on regional numeracy. We also observe higher numeracy among farmers in the eighteenth century than among agricultural workers.

We argue that this relationship can be explained by the behaviour of -often middlesized-farm households and the social structure in the regions dominated by these. Earlier studies emphasised advantages of farm households via four causal channels. Firstly, during crisis situations, farmers could benefit from their control over nutrients. This was very important for the development of numerical skills among their children. Agricultural sector workers could not provide high quality food to their children, especially not in crisis years, hence the children suffered from severe protein malnutrition (Baten, Crayen \& Voth, 2014). Apart from relatively good nutrition, some farmer children were not burdened with child labour, whereas day labourer households depended on child labour, inhibiting schooling (Tollnek \& Baten, 2017). Farmers were also more willing to invest in the skills of their children, as they would need them to run the farm, whereas the demand for skills by agricultural labourer parents might often have been lower. Finally, especially towards the end of the period, the elites who owned land prevented investment in the education of the poor. These hypotheses about farmer behaviour are consistent with the results of our study, as we find a consistently positive impact of the farmers' share. In contrast, comparing the farmers with all other occupational groups in the same regression, we do not find a significant farmer coefficient (only relative to day-labourers, farmers were more numerate). Consequently, the social structure in regions with a high farmers' share apparently also affected numeracy beyond the fact that some people were farmers. The only logical explanation for this are external effects: people with other occupations (for example, craftsmen and skill-intensive services) who lived in regions with a high farmers' share imitated -or behaved similar to-farmers, investing more time in their offspring's numeracy, requiring less child labour of them, providing slightly higher quality of nutrition than in other regions. We do not have direct qualitative evidence on this, but pre-

25. In a much later period, the share of landless workers declined again. According to CARMONA, RosÉs and SIMPSON (2019), the relative number of landless workers declined between 1860 and 1930. This was partly due to the falling ratio between land prices and rural wages and partly because of the exodus of the rural population to the cities. 
senting our indirect quantitative evidence on these external effects can be considered a first step to gain insights on this externality.

This also has wider implications for understanding the history of world inequality. Scheidel (2017) describes the process of growing inequality in world economic history as follows: farm size distribution played an important role. On one hand, kings and other rulers were interested in having a large share of farmers with medium sized plots, because their second and third sons were often recruited into the military. On the other hand, the nobility and others among wealthy social strata were keen on increasing their landownership and often forced small and medium sized farmers into servitude or agricultural labour and took over the land. A similar struggle can be observed for Spain during the Reconquista. In the western and north western Andalusian territories, the nobility and similarly interested religious orders succeeded in allocating a large share of the land to their own latifundia. In contrast, in central Spain and the south-eastern Kingdom of Granada, which was only conquered after a long period of peace, the Spanish Crown succeeded in distributing most of the land to medium and small farmers and later protecting them against the nobility which might have otherwise expropriated the land (Oto \& Romero, 2016).

We add an economic process to this mechanism: the reduction of the share of small and medium farms retards human capital formation and hence impedes economic development. Therefore, the struggle between the ruler and medium sized farm owners on the one hand and the nobility on the other not only had a military consequence but an economic one as well.

For the example of Spain, as late as the first half of the twentieth century, less than 1\% of holdings accounted for $57 \%$ of the area in western Andalusia (Carmona \& Simpson, 2007: 348). Although after the Spanish Civil War (1936-39) the active agrarian population began to decline in Spain, the provinces with latifundia in Andalusia continued being the ones with the greatest number of day labourers (Bernal, 1987:4); at the same time this was the region with the lowest literacy share (Arenas, 2016:352).

Do our findings have implications for the debate about the backwardness of the Spanish economy compared to other European economies until the first half of the twentieth century? Our results suggest that land inequality could have played a role because it hindered numeracy formation. This is consistent with the views of Pujol (2001) and Gallego (2001) who argued that there was a lower development due to income inequality and the persistence of a traditional nonindustrial agriculture. Our research is also in line with the authors who found that land inequality had consequences for economic development. Pas- 
cual and Sudrià (2002), Llopis (2002), Pinilla (2004) and others found that an unequal distribution of land did not encourage large landowners to invest in technology in the countryside, due in part to the existence of a cheap labour force in the rural world during the nineteenth and twentieth centuries (see also Palafox, 2002; Simpson, 2002; Clar \& Pinilla, 2009).

Our findings might also add an important notion to the investment issue in the late nineteenth century, as human capital differences tend to be persistent over time (Baten \& Juif, 2014): physical and human capital tend to be complementary (Galor, Moav \& Vollrath, 2009). The lack of numeracy in unequal regions might have reduced the profitability of physical capital investment due to this complementarity.

In sum, Spain can provide the most solid insights into the farmers' share and numeracy relationship, because it is the only country of the world for which occupations and ages are reported in local censuses for repeated years of the early modern period. We have evidence for the sixteenth, seventeenth and eighteenth centuries that allowed for the analysis of the effect of farmers' shares on numerical characteristics of the population. This certainly provides intriguing insights for Spain, but also more general conclusions about the role of farmers' shares in human capital formation throughout world economic history.

\section{ACKNOWLEDGEMENTS}

The authors would like to thank the anonymous reviewers of Historia Agraria for the comments to improve this article. An early version of this paper was presented at the European Historical Economics Society Conference held at the University of Tübingen in September 2017. This research has benefited from comments made by Daniel Oto-Peralías, Rowena Gray, Carmen Sarasúa and Andrés Sánchez Picón. The authors also thank Pilar Erdozáin and Luis Garrido for sharing the data of Olite and Laujar de Andarax respectively. Mari Carmen Pérez-Artés acknowledges the funding from the Ministerio de Economía y Competitividad of Spain (HAR2017-85601-C2-1-P).

\section{REFERENCES}

A'Hearn, B., Baten, J. \& Crayen, D. (2009). Quantifying Quantitative Literacy: Age Heaping and the History of Human Capital. The fournal of Economic History, 69 (3), 783-808. 
Álvarez Nogal, C. \& Prados de la Escosura, L. (2013). The Rise and Fall of Spain (1270-1850). The Economic History Review, 66 (1), 1-37.

Álvarez, B. \& Ramos, F. (2018). Human Capital and Earnings in Eighteenth-Century Castile. Explorations in Economic History, (67), 105-33.

ANDÚJAR, F. (2004). La cuestión morisca: De la general conversión a la guerra y el destierro. Andalucia en la historia, (4), 16-21. https://www.centrodeestudiosandaluces.es/publicaciones/descargar/374/documento/804/AH04.pdf

Arenas, C. (2016). Poder, economía y sociedad en el sur: Historia e instituciones del capitalismo andaluz. Sevilla: Centro de Estudios Andaluces, Consejeria de la Presidencia y Administracion Local.

Artola, M., Bernal, A. M. \& Contreras, J. (1978). El latifundismo, propiedad y explotación, SS. XVIII-XIX. Madrid: Ministerio de Agricultura.

BAteN, J. \& HIPPE, R. (2018). Geography, Land Inequality and Regional Numeracy in Europe in Historical Perspective. Fournal of Economic Growth, 23 (1), 79-109.

Baten, J., Crayen, D. \& Voth, H. J. (2014). Numeracy and the Impact of High Food Prices in Industrializing Britain, 1780-1850. Review of Economics and Statistics, 96 (3), 418-30. https://www.mitpressjournals.org/doi/pdf/10.1162/REST_a_00403

BATEN, J. \& JuiF, D. (2014). A Story of Large Land-Owners and Math Skills: Inequality and Human Capital Formation in Long Run Development, 1820-2000. Fournal of Comparative Economics, 42 (2), 375-401.

BATEN, J. \& SoHN, K. (2017). Numeracy in Early Modern Korea, Japan, and China:The Age-Heaping Approach. Fapan and the World Economy, (43), 14-22.

Baten, J., Szoltysek, M. \& CAmPestrini, M. (2017). “Girl Power” in Eastern Europe?: The Human Capital Development of Central-Eastern and Eastern Europe in the Seventeenth to Nineteenth Centuries and its Determinants. European Review of Economic History, 21 (1), 29-63. https://doi.org/10.1093/ereh/hew017

Beltrán, F. J. \& Martínez GalarRaga, J. (2018). Inequality and Education in Pre-Industrial Economies: Evidence from Spain. Explorations in Economic History, (69), 81101.

Beltrán, F. J., Díez Minguela, A., Martínez Galarraga, J. \& Tirado, D. (2018). Two Stories, One Fate: Age-Heaping and Literacy in Spain, 1877-1930. EHESWorking Papers in Economic History, (139).

Bermúdez MÉNDEZ, M. \& MARTíN, P. (2007). Coín 1752 según el Catastro de Ensenada: Transcripciones y análisis crítico. Málaga: Diputación Provincial de Málaga.

Bernal, A. M. (1987). Latifundios, jornaleros y paro agrícola. Revista de Estudios Andaluces, (8), 67-86.

BorRÁs, J. M. (2002). Mercado laboral, escolarizacion y empleo infantil en una comarca agricola e industrial (el Vallès Occidental, 1881-1910). Cuadernos de Historia Contemporánea, (24), 233-62. 
BorRás, J. M. (2003). Aprender trabajando: La actividad de niñas y niños en tierras de regadío (la Vega del Tajuña a comienzos del siglo xx). In C. SARAsÚa \& L. GÁlveZ MuÑoz (Eds.), ¿Privilegios o eficiencia?: Mujeres y hombres en los mercados de trabajo (pp. 157-83). Alicante: Universidad de Alicante.

Camarero, C. (2002). El Catastro de Ensenada, 1749-1759: Diez años de intenso trabajo y 80.000 volúmenes manuscritos. CT: Catastro, (46), 61-88. http://www. catastro.meh.es/documentos/publicaciones/ct/ct46/06.\%20Concepcion $\% 20$ Camarero.pdf

CARMona, J. \& Simpson, J. (2003). El laberinto de la agricultura española: Instituciones, contratos y organización entre 1850 y 1936. Zaragoza: Prensas Universitarias de Zaragoza.

CARMONA, J. \& Simpson, J. (2007). Economías de escala, organización de patrimonios y obstáculos a una reforma agraria: Andalucía, 1880-1936. In R. RoBLEDo \& S. M. LóPEZ GARCía (Coords.), ¿Interés particular, bienestar público?: Grandes patrimonios y reformas agrarias (pp. 343-62). Zaragoza: Prensas Universitarias de Zaragoza.

Carmona, J., Rosés, J. \& Simpson, J. (2019). The Question of Land Access and the Spanish Land Reform of 1932. The Economic History Review, 72 (2), 669-90

ClaR, E. \& Pinilla, V. (2009). The Contribution of Agriculture to Spanish Economic Development. In P. LaINs \& V. Pinilla (Eds.), Agriculture and Economic Development in Europe since 1870 (pp. 311-32). London: Routledge.

Clark, G. \& GraY, R. (2014). Geography is not Destiny: Geography, Institutions and Literacy in England, 1837-63. Oxford Economic Papers, 66 (4), 1042-69.

Clayburn la ForCe, J. (1964). Royal Textile Factories in Spain, 1700-1800. The fournal of Economic History, 24 (3), 337-63.

Crayen, D. \& BATEN, J. (2010). Global Trends in Numeracy 1820-1949 and its Implications for Long-Term Growth. Explorations in Economic History, 47 (1), 82-99. https:/www.sciencedirect.com/science/article/pii/S0014498309000357

Delgado, B. (1993). Historia de la educación en España y América: La educación en la España moderna (siglos XVI-XVIII). Madrid: Fundación Santa María.

GALLEGO, D. (2001). Historia de un desarrollo pausado: Integración mercantil y transformaciones productivas de la agricultura española (1800-1936). In J. PUjol et al. (Eds.), El pozo de todos los males: Sobre el atraso en la agricultura española contemporánea (pp. 147-214). Barcelona: Crítica.

Galor, O., Moav, O. \& Vollrath, D. (2009). Inequality in Landownership, the Emergence of Human-Capital Promoting Institutions, and the Great Divergence. The Review of Economic Studies, 76 (1), 143-79.

GARCía SANZ, A. (1996). Verlagssystem y concentración productiva en la industria pañera de Segovia durante el siglo XviII. Revista de historia industrial, (10), 11-36. 
GómeZ-I-AzNAR, E. (2019). Human Capital at the Beginnings of the $18^{\text {th }}$ Century Catalonia: Age-Heaping and Numeracy in a Changing Economy. Documentos de Trabajo (DT-AEHE), (1904). https://www.aehe.es/wp-content/uploads/2019/02/dt-aehe1904.pdf

GoNZÁLEZ DE Molina, M. (2014). La tierra y la cuestión agraria entre 1812 y 1931: Latifundismo versus campesinización. In M. GonzÁlez DE Molina (Ed.), La cuestión agraria en la historia de Andalucía: Nuevas perspectivas (pp. 21-60). Sevilla: Fundación Pública Andaluza, Centro de Estudios Andaluces.

Hanushek, E. A. \& Woessmann, L. (2012). Do Better Schools Lead to More Growth?: Cognitive Skills, Economic Outcomes, and Causation. Fournal of Economic Growth, 17 (4), 267-321.

Juif, D. \& Baten, J. (2013). On the Human Capital of Inca Indios before and after the Spanish Conquest:Was there a "Pre-Colonial Legacy"? Explorations in Economic History, 50 (2), 227-41. https://doi.org/10.1016/j.eeh.2012.12.002

Kagan, R. L. (1974). Students and Society in Early Modern Spain. Baltimore: Johns Hopkins University Press.

KaGAN, R. L. (1981). Universidad y sociedad en la España moderna. Madrid: Tecnos.

LLOPIS, E. (2002). Otras caras "menos amables" de la agricultura española contemporánea. Historia Agraria, (28), 179-98.

MARCoS, A. (2000). España en los siglos XVI, XVII y XVIII: Economía y sociedad. Barcelona: Crítica.

MATA, R. (1984). Transformación en regadío y evolución de la gran explotación agraria: El ejemplo de la Depresión del Guadalquivir. Agricultura y sociedad, (32), 193-228. https://www.mapa.gob.es/ministerio/pags/biblioteca/revistas/pdf_ays/a032_04.pdf

MATA, R. \& NARANJO, J. (1997). La Geografía rural y el estudio de la tenencia de la tierra en España. Asociación de Geógrafos Españoles.

NúÑEz, C. E. (1992). La fuente de la riqueza: Educación y desarrollo económico en la España contemporánea. Madrid: Alianza.

OTO, D. \& Romero, D. (2016). The Economic Consequences of the Spanish Reconquest: The Long-Term Effects of Medieval Conquest and Colonization. Fournal of Economic Growth, 21 (4), 409-64.

PALAfox, J. (2002). Las agriculturas españolas en los siglos XIX y XX: ¿El mejor de los mundos posibles? Historia Agraria, (28), 199-205.

Parejo, A. (2009). Historia económica de Andalucía contemporánea. Madrid: Síntesis.

PASCUA, M. J. DE LA (1989). Aproximación a los niveles de alfabetización en la provincia de Cádiz: Las poblaciones de Cádiz, El Puerto de Santa María, Medina Sidonia y Alcalá de los Gazules entre 1675-1800. Trocadero, Revista de Historia Moderna y Contemporánea, (1), 51-65. https://revistas.uca.es/index.php/trocadero/article/view/1251 PAscual, P. \& SudriÀ, C. (2002). Notas sobre El pozo... Historia Agraria, (28), 207-16. 
PeÑa, M. (Ed.) (2012). Breve historia de Andalucía. Sevilla: Fundación Pública Andaluza, Centro de Estudios Andaluces.

Pérez Picazo, M. T. \& Lemeunier, G. (1985). Agua y coyuntura económica: Las transformaciones de los regadíos murcianos (1450-1926). Geo Crítica, (58). http://www.ub.edu/geocrit/geocritica1-100/geo58.pdf

Pinilla, V. (2004). Sobre la agricultura y el crecimiento económico en España (18001935). Historia Agraria, (34), 137-62.

Ponsot, P. (1986). Atlas de historia económica de la Baja Andalucía (Siglos XVI-XIX). Sevilla: Editoriales Andaluzas Unidas.

Pujol, J. (2001). La historiografía del atraso o el atraso de la historiografía. In J. PujoL et al. (Eds.), El pozo de todos los males: Sobre el atraso en la agricultura española contemporánea (pp. 14-42). Barcelona: Crítica.

REHER, D. S. (1994). Ciudades, procesos de urbanización y sistemas urbanos en la península ibérica, 1550-1991. In M. GuÀrdiA, F. J. Monclús \& J. L. OYÓN (Eds.), Atlas histórico de las ciudades europeas. 1: Península Ibérica (pp. 1-30). Barcelona: Salvat.

REIS, J. (2005). Economic Growth, Human Capital Formation and Consumption in Western Europe before 1800. In R. C. Allen, T. Bengtsson \& M. Dribe (Eds.), Living Standards in the Past (pp. 195-225). Oxford: Oxford University Press.

Rodríguez, M. C. \& BenNassaR, B. (1978). Signatures et niveau culturel des témoins et accusés dans les procès d'inquisition du ressort du Tribunal de Tolède (1525-1817) et du ressort du Tribunal de Cordoue (1595-1632). Cahiers du monde hispanique et luso-brésilien, (31), 17-46. https://www.persee.fr/doc/carav_00080152_1978_num_ 31_1_2150

SANTIAGo-CABALlero, C. (2011). Income Inequality in Central Spain, 1690-1800. Explorations in Economic History, 48 (1), 83-96.

SARASÚA, C. (2002). El acceso de niños y niñas a los recursos educativos en la España rural del siglo XIX. In J. MARTínez CARRIÓN (Ed.), El nivel de vida en la España rural, siglos XVIII-XX (pp. 549-609). Alicante: Universidad de Alicante.

SCHEIDEL, W. (2017). The Great Leveler:Violence and the History of Inequality from the Stone Age to the Twenty-First Century. Princenton: Princenton University Press.

Schofield, R. \& ReHer, D. (1994). El descenso de la mortalidad en Europa. Boletín de la Asociación de demografía histórica, XII (1), 9-32.

Simpson, J. (2002). "El pozo", y el debate sobre la agricultura española. Historia Agraria, (28), 217-28.

Simpson, J. \& CARMONA, J. (2017). Too Many Workers or not Enough Land?: The Experience of Land Reform in Spain during the 1930s. Historia Agraria, (72), 37-68. http://www.historiaagraria.com/FILE/articulos/HA72_Simpson_Carmona.pdf 
Tollnek, F. \& Baten, J. (2017). Farmers at the Heart of the 'Human Capital Revolution'?: Decomposing the Numeracy Increase in Early Modern Europe. The Economic History Review, 70 (3), 779-809.

VIÑaO, A. (1999). Alfabetización y primeras letras (siglos XVI-XVII). In A. CastiLlo (Ed.), Escribir y leer en el siglo de Cervantes (pp. 39-84). Barcelona: Gedisa.

VINCENT, B. (1987). Lisants et non-lisants des royaumes de Grenade et de Valence a la fin du XVI siècle. In Centre National De la Recherche Scientifique (Ed.), De l'alphabétisation aux circuits du livre en Espagne, $X V I^{e}-X I X^{e}$ siècles (pp. 85-104). Paris, Centre National de la Recherche Scientifique. 


\section{APPENDIX}

TABLE 1

Number of observations by province and birth century

\begin{tabular}{|c|c|c|c|c|c|c|c|}
\hline \multicolumn{4}{|c|}{ N. total observations } & \multicolumn{4}{|c|}{ N.ㅇ observations with occupations } \\
\hline Province & $16^{\text {th }}$ & $17^{\text {th }}$ & $18^{\text {th }}$ & Province & $16^{\text {th }}$ & $17^{\text {th }}$ & $18^{\text {th }}$ \\
\hline Almería & & 224 & 1196 & Almería & & 130 & 733 \\
\hline Cáceres & & 22 & 130 & Cáceres & & 22 & 130 \\
\hline Badajoz & & 22 & 98 & Badajoz & & 22 & 98 \\
\hline Cáceres & & 41 & 324 & Cáceres & & 41 & 324 \\
\hline Cádiz & & 549 & 196 & Cádiz & & 379 & 180 \\
\hline Ciudad Real & & 9 & 109 & Ciudad Real & & 9 & 109 \\
\hline Córdoba & 253 & 1283 & 1300 & Córdoba & 202 & 630 & 905 \\
\hline Cuenca & & 35 & 208 & Cuenca & & 35 & 182 \\
\hline Granada & & 718 & 4613 & Granada & & 373 & 2167 \\
\hline Guadalajara & & 191 & 1442 & Guadalajara & & 85 & 735 \\
\hline Jaén & & 36 & 909 & Jaén & & 35 & 857 \\
\hline La Rioja & & 69 & 285 & La Rioja & & 61 & 258 \\
\hline Madrid & & 44 & 219 & Madrid & & 44 & 219 \\
\hline Málaga & & 110 & 1206 & Málaga & & 50 & 308 \\
\hline Murcia & & 191 & 939 & Murcia & & 191 & 939 \\
\hline Navarra & & & 337 & Navarra & & & 140 \\
\hline Sevilla & 303 & 549 & 337 & Sevilla & 222 & 424 & 303 \\
\hline Soria & & 306 & 1787 & Soria & & 292 & 1747 \\
\hline Toledo & & 740 & 5162 & Toledo & & 445 & 2780 \\
\hline Valencia & & & 324 & Valencia & & & 304 \\
\hline Valladolid & & 7 & 28 & Valladolid & & 7 & 28 \\
\hline & 556 & 5,146 & 21,704 & & 424 & 3,275 & 13,674 \\
\hline Total & 26,851 & & & Total &, 145 & & \\
\hline
\end{tabular}

Source: see section 3 of this text. 
TABLE 2

Descriptive statistics

\begin{tabular}{llcc}
\hline Variable & Obs. & Mean. & Std. Dev. \\
\hline Numerate & 26,851 & 0.57 & 0.50 \\
Farmers' share & 26,851 & 0.33 & 0.27 \\
Farmer & 26,851 & 0.14 & 0.35 \\
Day labourer & 26,851 & 0.17 & 0.38 \\
Age 23-32 & 26,851 & 0.33 & 0.47 \\
Age 43-52 & 26,851 & 0.22 & 0.42 \\
Age 53-62 & 26,851 & 0.15 & 0.35 \\
City* & 26,851 & 0.21 & 0.41 \\
Female & 26,851 & 0.34 & 0.47 \\
\hline
\end{tabular}

${ }^{\star}$ More than 20,000 inhabitants.

Note: at the individual level, all this variables are coded as 0 or 1 .

Source: see section 3 of this text. 
TABLE 3

The effect of land equality indicator farmers' share on individual numeracy

(the likelihood of individuals not to report a rounded age) using a linear probability model (LPM)

\begin{tabular}{|c|c|c|c|}
\hline & $(1)$ & $(2)$ & (3) \\
\hline \multirow[t]{2}{*}{ Farmers' share } & $12.14^{\star \star}$ & $9.65^{\star *}$ & $9.59^{* *}$ \\
\hline & $(0.034)$ & $(0.024)$ & $(0.032)$ \\
\hline \multirow[t]{2}{*}{ Farmer } & 0.38 & 0.36 & -0.02 \\
\hline & $(0.849)$ & $(0.888)$ & $(0.994)$ \\
\hline \multirow[t]{2}{*}{ Age 23-32 } & $2.75^{\star \star}$ & 0.13 & -1.25 \\
\hline & $(0.043)$ & $(0.960)$ & $(0.686)$ \\
\hline \multirow[t]{2}{*}{ Age 43-52 } & $-4.38^{*}$ & $-5.33^{*}$ & -3.92 \\
\hline & $(0.067)$ & $(0.071)$ & $(0.232)$ \\
\hline \multirow[t]{2}{*}{ Age 53-62 } & -2.15 & -10.04 & -3.93 \\
\hline & $(0.727)$ & $(0.161)$ & $(0.555)$ \\
\hline \multirow[t]{2}{*}{ City } & 1.19 & -0.44 & 2.16 \\
\hline & $(0.847)$ & $(0.948)$ & $(0.784)$ \\
\hline \multirow[t]{2}{*}{ Female } & 2.17 & 0.21 & \\
\hline & $(0.235)$ & $(0.908)$ & \\
\hline \multirow[t]{2}{*}{ Constant } & $24.61^{* * *}$ & $31.49^{* * *}$ & $24.92^{* *}$ \\
\hline & $(0.004)$ & $(0.001)$ & $(0.011)$ \\
\hline Observations (individuals) & 26,851 & 26,851 & 17,777 \\
\hline Adjusted R-squared & 0.04 & 0.04 & 0.04 \\
\hline Time FE & YES & YES & YES \\
\hline Region FE & YES & YES & YES \\
\hline
\end{tabular}

Robust p-Values are given in parentheses: ${ }^{\star \star \star} \mathrm{p}<0.01,{ }^{\star \star} \mathrm{p}<0.05,{ }^{\star} \mathrm{p}<0.1$.

Note: the dependent variable is 1 if the individual reported an unrounded age, 0 otherwise. The constant refers to male non-farmers living in local communities of fewer than 20,000 inhabitants aged 33-42. Time fixed effects are half centuries and region fixed effects are historical regions. We clustered by local community of birth and birth decade. We use the weights with the analytic weight function for the population of census (columns 2 and 3). We weighted by the population share of Aranda census by historical regions. This implies that local communities are stronger weighted, for which we have less observations relative to the total observations in the censuses. We use stata's analytic weights, including [aw=pop]. Our local communities are classified as follows according to the classification of the Aranda census by historical regions. Andalusia: Almería, Almuñécar, Bérchules, Bubión/Capileira, Colomera, Córdoba, Écija, Estepona, Granada, Iznalloz, Jaén, Laujar de Andarax, Loja, Málaga, Montilla, Navas de San Juan, Puerto de Santa María, Villanueva del Rey. Castilla La Nueva: Abenójar, Alovera, Arganda, Cavanillas, El Casar, Marchamalo, Móstoles, Pinto, Saelices, Toledo, Villanueva de la Torre, Yunquera de Henares. Castilla La Vieja: Adanero, Adradas, Aguaviva de la Vega, Aguilar y Montuenga, Alcubilla del Marqués, Aldea de San Esteban, Aldeasenor, Alentisque, Almaluez, Almarza, Almazán, Andaluz, Arcos de Jalón, Arévalo, Atauta, Fuente El Sol, Inestrillas, Logroño, Ontalvilla de Almazán, Torreandaluz, Ziria. Extremadura: Alía, Valdecaballeros. Murcia: Abanilla, Abrán, Albudeite, Lorca. Navarra y País Vasco: Olite. País Valenciano: Sueca. 
TABLE 4

The effect of the land equality indicator farmers' share on individual numeracy

(the likelihood of individuals not to report a rounded age) using a Logit model (marginal effects reported)

\begin{tabular}{lrrr}
\hline & $\mathbf{( 1 )}$ & $\mathbf{( 2 )}$ & $\mathbf{( 3 )}$ \\
\hline Farmers' share & $12.57^{\star *}$ & $9.88^{* *}$ & $9.84^{\star *}$ \\
& $(0.031)$ & $(0.021)$ & $(0.029)$ \\
Farmer & 0.45 & 0.44 & 0.06 \\
& $(0.829)$ & $(0.867)$ & $(0.983)$ \\
Age 23-32 & $2.88^{\star *}$ & 0.21 & -1.19 \\
& $(0.035)$ & $(0.936)$ & $(0.711)$ \\
Age 43-52 & $-4.53^{\star}$ & $-5.43^{\star}$ & -4.00 \\
& $(0.063)$ & $(0.077)$ & $(0.243)$ \\
Age 53-62 & -2.28 & -10.40 & -4.01 \\
& $(0.720)$ & $(0.157)$ & $(0.554)$ \\
City & 1.28 & -0.38 & 2.18 \\
Female & $(0.833)$ & $(0.955)$ & $(0.772)$ \\
& 2.23 & 0.25 & \\
Observations (individuals) & 26,851 & 26,851 & 17,777 \\
Time FE & YES & YES & YES \\
Region FE & YES & YES & YES \\
Pseudo R2 & $0.230)$ & $(0.894)$ & 0.0296 \\
\hline
\end{tabular}

Robust p-Values are given in parentheses: ${ }^{\star \star \star} \mathrm{p}<0.01,{ }^{\star \star} \mathrm{p}<0.05,{ }^{\star} \mathrm{p}<0.1$.

Note: the dependent variable is 1 if the individual reported an unrounded age, 0 otherwise. The constant refers to male non-farmers living in local communities of fewer than 20,000 inhabitants aged 33-42. Time fixed effects are half centuries and region fixed effects are historical regions. We clustered by local community of birth and birth decade. Weights establish representativeness for the regions included in columns 2 and 3 (see note on Table 3). 
TABLE 5

How large was the numeracy difference between farmers and agricultural labour (and non-agricultural occupations)?

\begin{tabular}{|c|c|c|}
\hline & (1) & (2) \\
\hline \multirow[t]{2}{*}{ Farmer } & $7.11^{\star \star *}$ & $4.76^{*}$ \\
\hline & $(0.004)$ & $(0.087)$ \\
\hline \multirow[t]{2}{*}{ All non-agric. occupations } & $10.18^{\star \star \star}$ & $9.73^{\star \star \star}$ \\
\hline & $(0.000)$ & $(0.000)$ \\
\hline \multirow[t]{2}{*}{ Age 23-32 } & -1.44 & -1.38 \\
\hline & $(0.489)$ & $(0.509)$ \\
\hline \multirow[t]{2}{*}{ Age 43-52 } & $-5.54^{\star \star \star}$ & $-6.01^{\star \star \star}$ \\
\hline & $(0.004)$ & $(0.002)$ \\
\hline \multirow[t]{2}{*}{ Age 53-62 } & -6.86 & $-10.71^{* *}$ \\
\hline & $(0.124)$ & $(0.034)$ \\
\hline \multirow[t]{2}{*}{ Constant } & $23.70^{\star \star *}$ & $46.88^{* * *}$ \\
\hline & $(0.000)$ & $(0.000)$ \\
\hline Observations & 15,901 & 15,901 \\
\hline Adjusted R-squared & 0.04 & 0.05 \\
\hline Time FE & YES & YES \\
\hline Region FE & YES & NO \\
\hline Local community FE & NO & YES \\
\hline
\end{tabular}

Robust p-Values are given in parentheses: ${ }^{\star \star \star} \mathrm{p}<0.01,{ }^{\star \star} \mathrm{p}<0.05,{ }^{\star} \mathrm{p}<0.1$.

Note: the dependent variable is 1 if the individual reported an unrounded age, 0 otherwise. The constant refers to agricultural labourers aged 33-42. Time fixed effects are half centuries, region fixed effects are historical regions and LC fixed effects are for each local community. Weights establish representativeness for the regions included (see note on Table 3). 